\title{
An estimation of the carcinogenic risk associated with the intake of multiple relevant carcinogens found in meat and charcuterie products ${ }^{\text {is }}$
}

\author{
Ángel Rodríguez Hernández a , Luis D. Boada ${ }^{\text {a,b,c }}$, Maira Almeida-González ${ }^{\text {a,b }}$, Zenaida Mendoza a , \\ Norberto Ruiz-Suárez a , Pilar F. Valeron ${ }^{\mathrm{a}, \mathrm{b}}$, María Camacho a ${ }^{\mathrm{a}}$, Manuel Zumbado ${ }^{\mathrm{a}, \mathrm{b}, \mathrm{c}}$, \\ Luis A. Henríquez-Hernández ${ }^{\mathrm{a}, \mathrm{b}}$, Octavio P. Luzardo ${ }^{\mathrm{a}, \mathrm{b}, \mathrm{c}, *}$ \\ a Toxicology Unit, Clinical Sciences Department, Universidad de Las Palmas de Gran Canaria, Spain \\ b Canary Islands Institute for the Research of Cancer (ICIC), Spain \\ c Spanish Biomedical Research Centre in Physiopathology of Obesity and Nutrition (CIBERObn), Spain
}

\section{H I G H L I G H T S}

- Quantification of 33 potential carcinogens in 58 meat and 42 charcuterie samples.

- Dietary intake of meat carcinogens in Spanish population ranged $0.5-293 \%$ of TDIs.

- Consumption of lamb, beef, pork, chicken, and Spanish chorizo poses carcinogenic risk.

- Recommendations of the maximum number of servings/month of each food are provided.

\section{G R A P H I C A L A B S T R A C T}
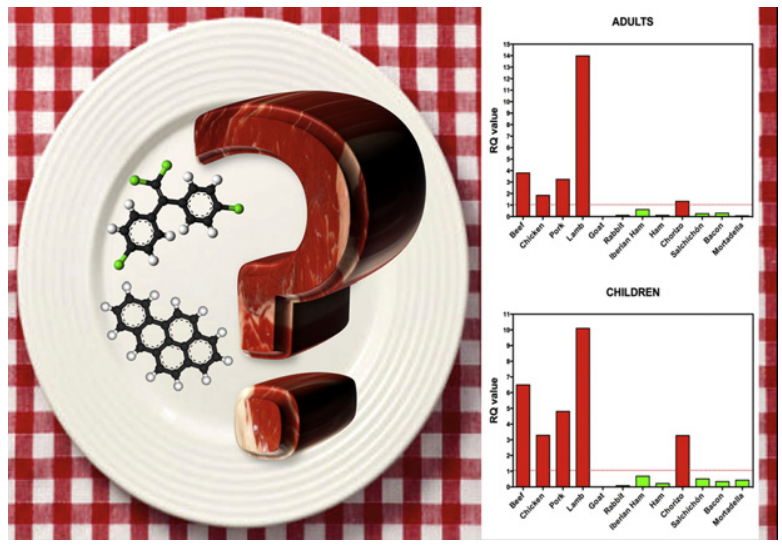

\section{A R T I C L E I N F O}

\section{Article history:}

Received 9 January 2015

Received in revised form 30 January 2015

Accepted 30 January 2015

Available online 4 February 2015

Editor: D. Barcelo

\section{Keywords:}

Carcinogenic potential

POPs

PAHs

Meat

\begin{abstract}
A B S T R A C T
Numerous epidemiological studies have demonstrated a link between excessive meat consumption and the incidence of various cancers, especially colorectal cancer, and it has been suggested that environmental carcinogens present in meat might be related to the increased risk of cancer associated with this food. However, there are no studies evaluating the carcinogenic potential of meat in relation to its content of carcinogens. Our purpose was to emphasize the relevance of environmental carcinogens existing in meat as a determinant of the association between cancer and meat consumption. Because within Europe, Spain shows high consumption of meat and charcuterie, we performed this study focusing on Spanish population. Based on the preferences of consumers we acquired 100 samples of meat and charcuterie that reflect the variety available in the European market. We quantified in these samples the concentration of 33 chemicals with calculated carcinogenic potential (PAHs, organochlorine pesticides, and dioxin-like PCBs). The carcinogenic risk of these contaminants was assessed for each food using a risk ratio based on the current consumption of meat and charcuterie and the maximum tolerable intake of these foods depending on the level of contamination by the carcinogens they contain. Our results indicate that the current consumption of beef, pork, lamb, chicken, and "chorizo", represents a relevant carcinogenic risk for
\end{abstract}

\footnotetext{
is Competing financial interest declaration: There are no actual or potential conflicts of interest to declare for any author.

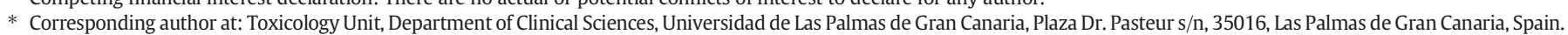
E-mail address: operez@dcc.ulpgc.es (O.P. Luzardo).
} 
Charcuterie

PCB

Organochlorine pesticides consumers (carcinogenic risk quotient between 1.33 and 13.98). In order to reduce carcinogenic risk, the study population should halve the monthly consumption of these foods, and also not to surpass the number of 5 servings of beef/pork/chicken (considered together).

(C) 2015 Elsevier B.V. All rights reserved.

\section{Introduction}

The consumption of certain foods of animal origin has been associated with the increased incidence of different types of cancer (Abid et al., 2014). Among them, the most clear epidemiological associations have been established with the consumption of red meat and processed meats (Abid et al., 2014; Kim et al., 2013). Thus, the consumption of red meat has been linked to an increase in total cancer mortality (Larsson and Orsini, 2014) as well as the increased incidence of colorectal cancer (Kim et al., 2013) and cancers of the esophagus (Zhu et al., 2014), liver (Freedman et al., 2010), pancreas (Pericleous et al., 2014), kidney (Alexander and Cushing, 2009), prostate (Abid et al., 2014), lung (Abid et al., 2014) and breast (Abid et al., 2014). The consumption of processed meat has also been strongly associated with an increased incidence of colorectal cancer (Aune et al., 2013; Kim et al., 2013) as well as kidney (Alexander and Cushing, 2009) and prostate (Alexander et al., 2010) cancers. According to the European cancer registries, in Spain, where this study is based, both the incidence and mortality of some of these cancers are above the average of the European Union, especially in men. This is the case for cancers of the colon and rectum, liver and lungs (Ferlay et al., 2013).

Although the food culture of Spain is contextualized within the framework of the Mediterranean diet, which is considered to be a pattern of consumption of healthy foods that protect against the development of the most common chronic diseases, including cancer (Giacosa et al., 2013), the most recent nutritional surveys show a decrease in adherence to the traditional Mediterranean diet in this country (Varela-Moreiras et al., 2013). Thus, overall meat consumption in Spain has steadily increased over the last few decades (Kanerva, 2013; Leon-Munoz et al., 2012), and currently, the meat industry is ranked in fifth position in the industrial sector of the Spanish economy and is ranked first among the agro-food industries (Chamorro et al., 2012). Thus, meat consumption in Spain has gone from being one of the lowest in the EU to reaching an average per capita consumption of $52.7 \mathrm{~kg} /$ year, which is even higher than the European average (51.2 kg/year) (Chamorro et al., 2012). More relevant is the consumption of charcuterie products, and Spain is at the head of the production and consumption of such meat products in Europe, behind Germany, France and Italy (Leon-Munoz et al., 2012).

Different studies have linked an increased risk of cancer from meat consumption with the presence of carcinogenic chemical substances in meat (Trafialek and Kolanowski, 2014), and according to the literature, the content of certain pollutants in meat is particularly relevant (Gasull et al., 2011). This is the case of organochlorine pesticides (OCPs) (Letta and Attah, 2013; Pardio et al., 2012; Schecter et al., 2010; Wang et al., 2011), dioxin-like polychlorinated biphenyls (PCB) (Costabeber et al., 2006; Malisch and Kotz, 2014; Schecter et al., 2010; Schwarz et al., 2014), and especially polycyclic aromatic hydrocarbons (PAHs) (Gilsing et al., 2012; Liao et al., 2014).

During the past 30 years, many of these substances have been highlighted as a concern (Boada et al., 2007, 2012, 2014; Casals-Casas and Desvergne, 2011; Dorgan et al., 1999; Knerr and Schrenk, 2006; Valeron et al., 2009) and have been the subject of extensive study and international regulation in part because of their carcinogenic potential (Dorgan et al., 1999; Knerr and Schrenk, 2006; Liao et al., 2014). A variety of the most common pollutants in meat from the abovementioned chemical groups have been classified in group B of carcinogenicity (WHO, 2014). Although cancer slope factors (CSF) have been calculated for all of these probable carcinogens (EPA, 2014) and this would allow an estimate of the risk of cancer associated with continuous exposure to them through foodstuff, very few studies have attempted to estimate the carcinogenic risks that are associated with the current pattern of consumption of the pollutants associated with meat and meat products (Trafialek and Kolanowski, 2014).

In this study, we first determined the concentrations of 7 PAHs, 18 PCBs and 8 OCPs for which the CSFs have been calculated in a total of 100 samples of meat and charcuterie products that are most commonly consumed by the studied population. Because it is well known that continued exposure to carcinogens, even at very low doses, is not without risk, the main objective of this study was to use these data to estimate the carcinogenic risk associated with the current level of meat consumption by these consumers. For this purpose, we used the data of food consumption (AECOSAN, 2011) and applied the methodology that has been recently used to estimate the carcinogenic risk associated with food intake (Yu et al., 2014). Finally, we calculated the number of monthly servings of meat and charcuterie products that would be exempt from carcinogenic risk to provide a recommendation for consumption.

\section{Materials and methods}

\subsection{Sampling}

From January to March 2014, we randomly acquired samples of meat and charcuterie products from multinational retailers settled in the Canary Islands (Spain). Therefore, all the products sampled came from large suppliers who serve the entire European territory, and as a consequence our results could be extrapolated to the entire European population, only considering their differentiated dietary habits. According the most appreciated choices of Spanish consumers (AECOSAN, $2011)$ we bought meat samples: beef $(n=14)$, chicken $(n=16)$, pork $(\mathrm{n}=8)$, lamb $(\mathrm{n}=8)$, goat $(\mathrm{n}=6)$, and rabbit $(\mathrm{n}=6)$; and also traditional charcuterie products: Iberian cured ham ("serrano ham") $(n=8)$, ham $(n=7)$, Spanish chorizo $(n=8)$, Spanish drycured sausage "salchichón" $(n=7)$, bacon $(n=6)$, and Italian mortadella $(n=6)$.

The samples were processed immediately upon arrival at the laboratory. Each individual sample was finely chopped with a knife and was then ground using a stainless steel domestic food processor. The lipid content of the samples was determined in triplicate by the modified Gerber method as previously described (de Langen, 1963), to obtain the final lipid-corrected values. Then, all of the samples were frozen at $-18^{\circ} \mathrm{C}$ until analysis.

\subsection{Chemical analyses}

Organic solvents (>99.9\%) were purchased from Fisher Scientific (Leicestershire, United Kingdom). Diatomaceous earth was purchased from Sigma-Aldrich (St. Louis, USA). Bio-Beads SX-3 were purchased from BioRad Laboratories (Hercules, USA). Standards of OCPs, PCBs, and the internal standards (ISs, PCB 202, p,p'-DDE-d8, phenanthene$\mathrm{d} 10$, tetrachloro-m-xylene, and heptachloro epoxide cis) were purchased from Dr. Ehrenstorfer (Augsburg, Germany). Standards of PAHs were purchased from Absolute Standards, Inc. (Connecticut, USA). All standards were neat compounds (purity ranged from $97 \%$ to $99.5 \%$ ). Solutions diluted from $0.05 \mathrm{ng} / \mathrm{mL}$ to $100 \mathrm{ng} / \mathrm{mL}$ in cyclohexane were used for calibration curves.

We quantified the levels of 8 OCPs: p,p'-DDT, p,p'-DDE, p, p'-DDD, hexachlorobencene (HCB), and the four isomers of hexachlorocyclohexane $(\alpha-, \beta-, \gamma-, \delta-H C H)$. We also determined 18 PCB congeners, including marker-PCBs (M-PCBs) and dioxin-like PCBs (DL-PCBs): IUPAC 
numbers $28,52,77,81,101,105,114,118,123,126,138,153,156$, $157,167,169,180$, and 189. We also included 7 PAHs listed as carcinogens (EPA, 2001): benzo(a)anthracene, benzo(a)phenanthrene (chrysene), benzo(a)pyrene, benzo(b)fluoranthene, benzo(k)fluoranthene, dibenzo(a,h)anthracene, and indeno(1,2,3-cd)pyrene.

We first extracted the fat from the meat and charcuterie samples because all of the contaminants included in this study are completely lipid-soluble and therefore are found in the lipid fraction of tissues. Thus, the samples ( $5 \mathrm{~g}$ ) were homogenized in $5 \mathrm{ml}$ of ultrapure water with a disperser (Ultra-turrax, IKA, China). This homogenate was spiked with a $10 \mathrm{ppm}$-ISs mix in acetone (100 ppb, final concentration) and was mixed with $30 \mathrm{~g}$ of diatomaceous earth to absorb any moisture. The extraction and clean-up method followed the procedures recommended by the European Standard for the determination of pesticides and PCBs in fatty foods (EN, 1996a,b), which had been previously validated in our laboratory for different fatty samples of animal origin (Luzardo et al., 2014). This method achieved acceptable recoveries that ranged between $71.5 \%$ and $103.2 \%$. All of the individual measurements were corrected by the recovery efficiency for each analyte. Briefly, for the fat extraction, we used a Soxtec ${ }^{\mathrm{TM}} 2055$ Auto Fat Extraction (Foss ${ }^{\circledR}$ Analytical, Hilleroed, Denmark) apparatus, which consisted of an extraction unit, a control unit and a drive unit. The samples were placed into the extraction unit, and $20 \mathrm{ml}$ of dichloromethane were added to each of the extraction cups in a closed system, and the cups were heated using an electric heating plate. The three-step extraction consisted of boiling, rinsing, and solvent recovery. The solvent was evaporated in a rotary evaporator (Hei-VAP Advantage ${ }^{\mathrm{TM}}$, Heidolph Instruments ${ }^{\circledR}$, Schwabach, Germany) at $40{ }^{\circ} \mathrm{C}$ to prevent analyte losses. The results were calculated as the total amount of fat $(\mathrm{g})$ per $100 \mathrm{~g}$ of tissue. Using a precision balance, the fat obtained was carefully weighted into a zeroed glass tube. The weighted fat was dissolved in $2 \mathrm{ml}$ of cyclohexane/ethyl acetate (1:1) and subjected to purification by gel permeation chromatography (BioBeads SX-3) using cyclohexane/ethyl acetate (1:1) at a constant flow of $2 \mathrm{ml} / \mathrm{min}$ as the eluent. The first 25minute elution volume, which contained the great majority of lipids (>98\%), was discarded. The $25-85$ min elution volume $(120 \mathrm{ml})$, which contained all of the analytes that were co-extracted with the fat, was collected. The sample was concentrated using a rotary evaporator, and finally, the solvent was evaporated to dryness under a gentle nitrogen stream. The residue was then reconstituted in $1 \mathrm{~mL}$ of cyclohexane and the sample was transferred to a GC vial that was used for the chromatographic analysis. The amount of pollutants per gram of fat was obtained by multiplying by the corresponding correction factor.

Gas chromatography-mass spectrometry analyses of 33 carcinogenic compounds, plus ISs, were performed in a single run on a Thermo Trace GC Ultra coupled to a Triple Quadrupole Mass Spectrometer Quantum XL (Thermo Fisher Scientific Inc., Waltham, MA, USA) as previously described (Camacho et al., 2013, 2014), and identifications were done using an electron ionization (EI)-MS/MS library that was specially created for the target analytes under our experimental conditions. All of the measurements were performed in triplicate, and we used the means for the calculations. In each batch of samples, three controls were included for every 18 vials ( 6 samples): a reagent blank consisting of a vial containing only cyclohexane; a vial containing $2 \mathrm{ng} / \mathrm{mL}$ of each of the pollutants in cyclohexane; and an internal laboratory quality control (QC) consisting of melted meat fat spiked with a mixture of all of the pesticides $(20 \mu \mathrm{g} / \mathrm{kg})$, and processed using the same method that was used for the samples. The results were considered to be acceptable when the quantification of the analytes in the QC was within $15 \%$ of the deviation of the theoretical value.

\subsection{Dietary intake estimates and calculations}

The estimated total daily intake per body weight of each of the contaminants was calculated by multiplying the respective concentrations of contaminants in each food type (median values expressed in $\mathrm{ng} / \mathrm{g}$ fresh product) by the average daily consumption of these foodstuffs by the study population. Two groups were considered: adults (average weight $70.1 \mathrm{~kg}$ ) and children (average weight $30.4 \mathrm{~kg}$ ). For the calculations, when the concentration of a given contaminant was below the limit of quantification (LOQ) but above the limit of detection (LOD) of the technique, the value was assumed to be $1 / 2 \mathrm{LOQ}$. Otherwise the value was considered to be 0 . Food consumption data were obtained from the Spanish Agency for Consumer Food Safety and Nutrition (AECOSAN) (AECOSAN, 2011).

We expressed the total value of OCP residues ( $\sum$ OCPs) as the sum of the 8 OCPs (and metabolites) measured; the total value of DDTs $\left(\sum D D T\right)$ as the sum of the measured values of $\mathrm{p}, \mathrm{p}^{\prime}$-DDT, $\mathrm{p}, \mathrm{p}^{\prime}$-DDE and p, $\mathrm{p}^{\prime}-\mathrm{DDD}$; and the total value of $\mathrm{HCH}$ residues $\left(\sum \mathrm{HCH}\right)$ as the sum of the $4 \mathrm{HCH}$ isomers measured. Similarly, we expressed the total value of $\mathrm{PCB}$ residues ( $\sum$ PCBs) as the sum of the 18 PCB congeners measured. In addition, we expressed the total value of the marker $\mathrm{PCB}$ residues ( $\sum \mathrm{M}-\mathrm{PCBs}$ ) as the sum of the congeners $\# 28,52,101,118$, 138,153 and 180 , and the total value of dioxin-like PCBs ( $\sum$ DL-PCBs) as the sum of the measurements of the 12 individual congeners \#77, $81,105,114,118,123,126,156,157,167,169$ and 189. For the risk estimation, we calculated the potential toxicity for the DL-PCBs (in terms of toxic equivalence to dioxins; TEQs) using the toxic equivalency factors (Van den Berg et al., 2006). Finally, we also considered the total content of carcinogenic PAHs ( $\sum$ c-PAHs) following the EFSA recommendations (EFSA, 2008). For the risk estimation, we additionally used toxic equivalency factors (TEFs), which are established for the carcinogenic PAHs (Nisbet and LaGoy, 1992), to express the results in the form of benzo[a]pyrene toxic equivalents $\left(\mathrm{B}[\mathrm{a}] \mathrm{P}_{\mathrm{eq}}\right)$.

The CSF values of the carcinogens included in this study were taken from the EPA's IRIS and Yu et al. (2014) and were as follows: 1 per $\mathrm{mg} / \mathrm{kg} \mathrm{day}^{-1}$ for marker PCBs (based on Aroclors 1260 , $1254,1242$ and 1061$) ; 1.1 \times 10^{5}$ per $\mathrm{mg} / \mathrm{kg} \mathrm{day}^{-1}$ for DL-PCBs (based on 2,3,7,8-tetrachlorodibenzo-p-dioxin (2,3,7,8,-TCDD)); 0.34 per $\mathrm{mg} / \mathrm{kg} \mathrm{day}^{-1}$ for DDTs; 1.8 per $\mathrm{mg} / \mathrm{kg} \mathrm{day}^{-1}$ for HCHs (as there are no CSF values listed for total $\mathrm{HCHs}$ we used the values listed for $\beta$ - and $\gamma-\mathrm{HCH}) ; 1.6$ per $\mathrm{mg} / \mathrm{kg} \mathrm{day}^{-1}$ for HCB; and 7.3 per $\mathrm{mg} / \mathrm{kg} \mathrm{day}^{-1}$ for PAHs (based on benzo[a]pyrene).

\subsection{Carcinogenic risk calculation}

To estimate whether chemical contamination by carcinogens of meat and charcuterie products endangers the Spanish population, we applied the risk assessment index, known as the risk quotient (RQ), using the methodology that has been used for other food groups, such as fish (Yu et al., 2014). Thus, in this work, the RQ is defined as the ratio between the current consumption of meat and charcuterie products $\left(R_{\text {meat }}\right)$ and the maximum tolerable consumption of these products, which is calculated taking into account the concentrations of carcinogens in these foods $\left(C R_{\text {lim }}\right)$ as follows:

$$
C R_{\text {lim }}=\frac{A R L \cdot B W}{\sum_{m=1}^{X} C_{m} \cdot C S F_{m}}
$$

where $C R_{\text {lim }}$ is the maximum allowable consumption rate ( $\mathrm{kg} /$ day) for a particular meat or charcuterie product; $A R L$ is the maximum acceptable individual lifetime risk level (dimensionless), and a value of $10^{-5}$ was used in this study (Yu et al., 2014); $B W$ is the body weight ( $\mathrm{kg}$ ); $C_{m}$ is the median concentration of contaminant $m$ in a particular meat or charcuterie product $(\mathrm{mg} / \mathrm{kg})$ as determined in this study; and $C S F_{m}$ is the cancer slope factor of a contaminant $m$ with carcinogenic potential. In the case of multiple contaminants with the same CSF, their concentrations in a particular meat or charcuterie product were summed (from $m=1$ to $m=\mathrm{x}$ ). 
Then, the RQ for each food item and contaminant was calculated as follows:

$\mathrm{RQ}=\frac{R_{\text {meat }}}{C R_{\text {lim }}}($ for a single contaminant $)$

$\mathrm{RQ}=R_{\text {meat }} \cdot \sum_{m=1}^{x} \frac{1}{C R_{\text {lim }}}$ (for multiple contaminants $)$.

Thus, if the value of RQ is equal to or less than 1 , it is assumed that there is no carcinogenic risk associated with the ingestion of contaminants through the consumption of a particular type of meat or charcuterie product. Otherwise, the population is considered to be at carcinogenic risk when RQ is greater than 1 .

\subsection{Calculation of the recommended consumption of meat and charcuterie products}

The current and recommended consumption patterns (expressed in servings/month following EPA's recommendations (Yu et al., 2014)) were calculated according to the formulas:

$C_{m m}=\frac{R_{\text {meat }} \cdot T P}{M S}$

$R C_{m m}=\frac{R Q}{C_{m m}}$

where $C_{m m}$ is the current number of meals per month for each type of meat or charcuterie product; $M S$ is the meal size $(0.15 \mathrm{~kg}$ meat $/$ meal, and $0.07 \mathrm{~kg}$ charcuterie product $/$ meal); TP is the averaged time period (month $=30.44$ days); and $R C_{m m}$ is the recommended maximum number of servings of each food per month.

\subsection{Statistical analysis}

We used PASW Statistics v 19.0 (SPSS Inc., Chicago, IL, USA) to manage the database of the study and to perform the statistical analyses. Normality was examined using the Kolmogorov-Smirnov test. The distributions of carcinogens in the meat and charcuterie products lacked normality and homoscedasticity; therefore, we used non-parametric tests (the Mann-Whitney and Kruskal-Wallis tests). The results are reported as the medians and interquartile ranges. Probability levels of less than 0.05 (two tailed) were considered statistically significant.

\section{Results and discussion}

3.1. Occurrence of persistent organic pollutants with carcinogenic potential in meat and charcuterie products

An average of 19 residues per sample were found (range 12-24), independent of the food item considered, varying only in the concentration and frequency of detection among the different food types. We present a summary of the obtained results (median and percentiles 25th-75th; p25-75) for each contaminant (or group of contaminants) in each food type in Table 1, either as individual compounds or as the sum of individual compounds according to their carcinogenic potential.

When we consider the results obtained directly from the fat of the meat or charcuterie product, measured in $\mathrm{ng} / \mathrm{g}$ lipid weight (l.w.), it is interesting to note that, in general, for each carcinogen or group of carcinogens, the results were very similar between the different types of food, with little variation. Thus, for $\sum$ DDTs no differences were found between meat and charcuterie products. The median value for the total sample was $80.1 \mathrm{ng} / \mathrm{g}$ l.w. (P25-75 = 53.2-98.6 ng/g l.w.). Only the values in the fat of lamb and goat departed considerably and were significantly higher than the rest $(p<0.001$ for lamb fat, and $p<0.01$ for goat fat). In the case of $\sum \mathrm{HCHs}$, we found significant differences between meat (median 17.4 ng/g l.w.; P25-75 = 11.5-30.1 ng/g l.w.) and charcuterie products ( $4.1 \mathrm{ng} / \mathrm{g}$ l.w., P25-75 $=3.1-5.7 \mathrm{ng} / \mathrm{g}$ l.w.) $(p<0.01)$. Again, in this case, the highest values were found in samples of lamb fat $(p<0.005)$ and goat fat $(p<0.05)$. In the case of HCB it is interesting to note that lamb meat fat values departed considerably from the median value, being as much as 35 times higher than the median of the whole group of samples (median 27.2 ng/g l.w.; P25-75 = 16.9$47.1 \mathrm{ng} / \mathrm{g}$ l.w.), $(p<0.001)$. Additionally we found higher levels of this pollutant in the fat of goat meat than in the rest of the foods $(p<0.05$, Table 1). The values of the total amount of PCBs ( $\sum$ PCBs) were also

Table 1

Concentrations of contaminants with carcinogenic potential (ng $\mathrm{g}^{-1}$ fat) in samples of meat and charcuterie products most consumed by Spanish population

\begin{tabular}{|c|c|c|c|c|c|c|c|c|c|c|c|c|c|c|}
\hline & \multicolumn{2}{|l|}{$\sum$ DDTs } & \multicolumn{2}{|l|}{$\sum \mathrm{HCHs}$} & \multicolumn{2}{|l|}{$\mathrm{HCB}$} & \multicolumn{2}{|c|}{$\sum \mathrm{M}-\mathrm{PCBs}$} & \multicolumn{2}{|c|}{$\sum$ DL-PCBs } & \multicolumn{2}{|c|}{$\sum \mathrm{TEQ}_{\mathrm{DL}-\mathrm{PCBS}}$} & \multicolumn{2}{|c|}{$\sum \mathrm{B}[\mathrm{a}] \mathrm{P}_{\mathrm{eq}}$} \\
\hline & Median & P25-75 & Median & P25-75 & Median & P25-75 & Median & P25-75 & Median & P25-75 & Median & P25-75 & Median & P25-75 \\
\hline \multicolumn{15}{|l|}{ Meat } \\
\hline \multirow[t]{2}{*}{ Beef } & 87.5 & 33.1 & 6.4 & 1.8 & 13.2 & 3.7 & 102.3 & 56.1 & 8.9 & 2.3 & 0.4 & 0.1 & 1.4 & 1.2 \\
\hline & & 320.1 & & 75.9 & & 52.8 & & 240.9 & & 23.1 & & 1.3 & & 6.7 \\
\hline \multirow[t]{2}{*}{ Chicken } & 74.3 & 16.7 & 13.2 & 3.2 & 31.3 & 11.2 & 155.1 & 23.1 & 2.4 & 0.5 & 0.2 & 0.1 & 3.9 & 0.7 \\
\hline & & 231.0 & & 69.3 & & 132.3 & & 300.3 & & 10.3 & & 0.8 & & 35.8 \\
\hline \multirow[t]{2}{*}{ Pork } & 85.8 & 75.9 & 21.5 & 3.3 & 16.5 & 2.1 & 173.3 & 128.7 & 3.3 & 1.1 & 0.4 & 0.1 & 4.9 & 1.2 \\
\hline & & 399.3 & & 174.9 & & 75.9 & & 330.2 & & 11.3 & & 0.8 & & 9.6 \\
\hline \multirow[t]{2}{*}{ Lamb } & 603.9 & 85.8 & 31.4 & 6.3 & 985.1 & 287.1 & 153.5 & 102.3 & 7.0 & 0.8 & 0.5 & 0.2 & 1.5 & 0.1 \\
\hline & & 3039.1 & & 1168.8 & & 1439.6 & & 247.5 & & 26.4 & & 1.3 & & 5.1 \\
\hline \multirow[t]{2}{*}{ Goat } & 188.1 & 151.8 & 29.7 & 23.1 & 85.8 & 79.2 & 283.8 & 198.1 & 4.9 & 0.4 & 1.2 & 0.5 & 16.8 & 0.7 \\
\hline & & 224.4 & & 36.3 & & 92.4 & & 369.6 & & 9.9 & & 1.9 & & 32.9 \\
\hline \multirow[t]{2}{*}{ Rabbit } & 52.8 & 36.3 & 13.2 & 6.6 & 47.4 & 39.6 & 137.0 & 59.4 & 0.6 & 0.9 & 0.2 & 0.1 & 0.5 & 0.1 \\
\hline & & 99.0 & & 16.5 & & 237.6 & & 148.5 & & 6.2 & & 0.3 & & 1.3 \\
\hline \multicolumn{15}{|l|}{ Meat products } \\
\hline \multirow[t]{2}{*}{ Iberian cured ham } & 100.7 & 29.7 & 3.3 & 1.2 & 28.1 & 22.1 & 82.5 & 61.2 & 1.7 & 1.1 & 0.1 & 0.1 & 0.7 & 0.2 \\
\hline & & 42.9 & & 11.4 & & 39.5 & & 92.4 & & 5.4 & & 0.3 & & 1.2 \\
\hline \multirow[t]{2}{*}{ Ham } & 36.3 & 82.5 & 6.5 & 1.8 & 11.2 & 1.8 & 133.7 & 53.2 & 4.9 & 2.3 & 0.3 & 0.1 & 1.3 & 0.4 \\
\hline & & 108.9 & & 16.5 & & 22.9 & & 204.6 & & 7.6 & & 0.4 & & 2.6 \\
\hline \multirow[t]{2}{*}{ Spanish chorizo } & 54.4 & 29.7 & 5.4 & 2.1 & 18.2 & 5.3 & 110.6 & 29.5 & 2.7 & 0.8 & 0.4 & 0.2 & 38.8 & 12.8 \\
\hline & & 85.8 & & 18.3 & & 19.8 & & 151.8 & & 9.6 & & 0.7 & & 96.7 \\
\hline \multirow[t]{2}{*}{ Spanish salchichón } & 74.2 & 2.3 & 3.1 & 1.1 & 26.4 & 32.1 & 105.6 & 12.1 & 0.8 & 0.2 & 0.2 & 0.1 & 0.2 & 0.1 \\
\hline & & 115.5 & & 7.2 & & 46.8 & & 145.6 & & 3.4 & & 0.7 & & 2.3 \\
\hline \multirow[t]{2}{*}{ Bacon } & 42.9 & 36.3 & 2.8 & 0.8 & 46.2 & 29.3 & 123.8 & 75.1 & 0.6 & 0.3 & 0.1 & 0.1 & 0.4 & 0.1 \\
\hline & & 49.5 & & 4.3 & & 52.8 & & 232.4 & & 1.3 & & 0.6 & & 1.7 \\
\hline \multirow[t]{2}{*}{ Italian mortadella } & 92.4 & 36.3 & 4.9 & 2.8 & 26.4 & 13.2 & 145.2 & 97.6 & 2.5 & 0.4 & 0.2 & 0.1 & 0.5 & 0.1 \\
\hline & & 191.4 & & 7.4 & & 51.9 & & 214.7 & & 7.6 & & 0.6 & & 1.5 \\
\hline
\end{tabular}


quite homogeneous among the different types of food (median 138.1 ng/g l.w.; P25-75 = 111.8-159.8 ng/g l.w.). Again, the values found in the fat of meat of one of the small ruminant species considered (goat) were above average ( $p<0.01$, Table 1$)$. The PCB concentrations were completely dominated by congeners $118,138,153$ and 180 , and thus, the $\sum$ M-PCBs contributed 92.3\%-99.7\% to the $\sum$ PCBs. Therefore, the TEQ ${ }_{D L-P C B s}$ levels were low (median from 0.1 to $1.2 \mathrm{pg} / \mathrm{g}$ l.w.) (Table 1). Finally, with respect to the c-PAHs (expressed as B[a] $\mathrm{P}_{\text {eq }}$ ), two types of fat samples had higher values than the rest (median $1.4 \mathrm{ng} / \mathrm{g}$ l.w.; IqQ $=0.5-4.7 \mathrm{ng} / \mathrm{g}$ l.w.), namely, goat meat fat $(p<0.01)$ and Spanish chorizo fat $(p<0.001)$.

We have considered it also interesting to show our findings graphically by expressing the concentrations of the pollutants relative to the food wet weight (as they are finally consumed), as this more clearly shows the real differences in contamination among different products (Fig. 1). In this figure it can be appreciated that enormous differences exist among foods. The biggest burden of OCPs and PCBs is exhibited by lamb meat and bacon, and for c-PAHs the most contaminated foods are lamb meat and Spanish chorizo.

3.2. Daily intake of carcinogenic pollutants through the consumption of meat and charcuterie products in the Spanish population

In Table 2, we summarized the dietary intake of all of the contaminants by food item, calculated for children and adults on the basis of their different consumption habits and average weights.

First, with regard to the intake of OCPs, our results show that the meat-related estimated daily intake (EDI) of $\sum$ DDTs for people living in Spain is $88.8 \mathrm{ng} / \mathrm{kg}$ b.w. day in adults and $142.1 \mathrm{ng} / \mathrm{kg}$ b.w. day in children, and the consumption of meat is the main contributor of this exposure (mainly lamb, followed by beef, pork, and chicken). The contribution of charcuterie products to this exposure can be considered comparatively minimal (5.95\% in adults and $9.62 \%$ in children). The EDI of $\sum \mathrm{HCHs}$ through meat and charcuterie products is $24.3 \mathrm{ng} / \mathrm{kg}$ b.w. day in adults
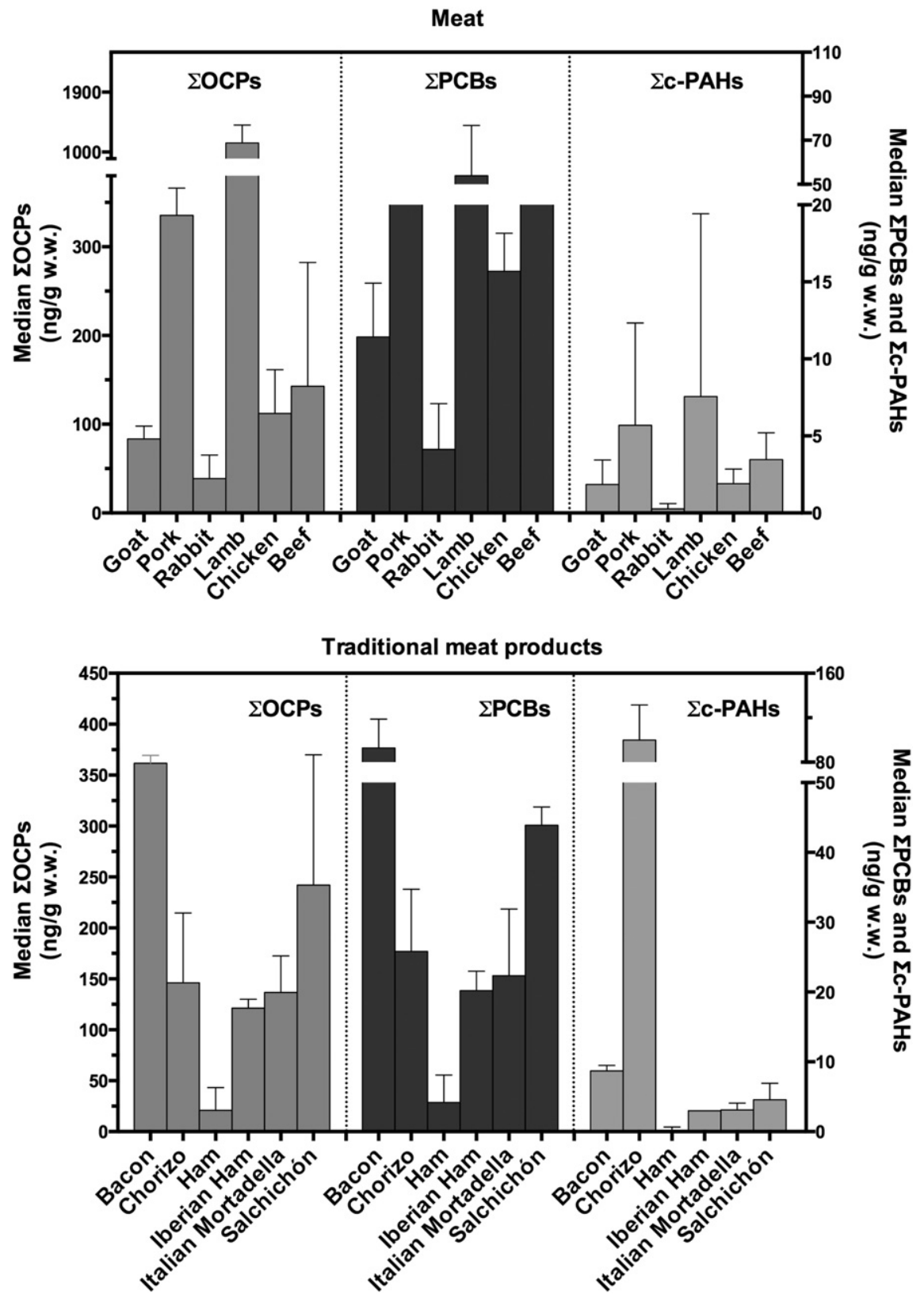

Fig. 1. Levels of $\sum$ OCPs, $\sum$ PCBs, and $\sum$ c-PAHs in meat (fresh products). Upper panel, meats. Lower panel, processed meats (traditional charcuterie products). 
and $36.9 \mathrm{ng} / \mathrm{kg}$ b.w. day in children. As for $\sum$ DDTs, the main contributors of these pollutants are lamb, pork and beef meats, among the foods studied (approximately 92\%). With regard to the intake of HCB, it is important to note that the highest contribution of this contaminant is related to the consumption of lamb meat ( $83 \%$ of the total). In this case, as in the above, the contribution of the consumption of charcuterie products to the intake of this pesticide is relatively low, with the exception of Iberian ham (Table 2). With regard to exposure to PCBs, charcuterie products pose a relevant contribution, particularly Iberian ham and Spanish chorizo, although it is considerably less than the contribution of meats. Thus, the main dietary intake of these contaminants within this food group consumption is from beef, followed by pork. The contribution of charcuterie product to PCB intake is relatively low, especially for DL-PCBs. Finally, the daily intake of $\sum \mathrm{c}-\mathrm{PAHs}$, in terms of $\mathrm{B}[\mathrm{a}] \mathrm{P}_{\mathrm{eq}}$, greatly depended on the type of meat or charcuterie product consumed. In our study the highest exposure to these carcinogens is through the consumption of chorizo, which contributes over $55 \%$ of the total.

\subsection{The carcinogenicity $R Q$ of the current consumption of meat and charcu- terie products}

The $C R_{\text {lim }}$ values, calculated for each one of the food items studied are presented in Table 3. As it can be observed the current pattern of consumption of this population implies that some of these limits are exceeded through the consumption of meat and charcuterie products. Thus, the $C R_{\text {lim }}$ of $\sum$ M-PCBs is clearly exceeded by the consumption of beef and pork in adults and children, and in the latter, also by the consumption of chicken meat. The pork consumption also appears to exceed the $\sum \mathrm{HCHs} C \mathrm{R}_{\text {lim }}$ in children. Finally, the current consumption of lamb exceeds the $C R_{\text {lim }}$ for $\sum$ DDTs, $\sum$ HCHs and $\sum$ HCB in both children and adults.

In Fig. 2, we present the calculated RQ for all of the carcinogens and foods for both, adults and children. Thus, the RQ for the carcinogenic effects of multiple pollutants ranges between 0.02 and 13.98 for adults and between 0.01 and 10.98 for children. The lowest risk is associated with the consumption of goat meat and the highest is associated with the consumption of lamb meat. As noted in Fig. 2, in both age groups, the current consumption of beef, chicken, pork, lamb, and Spanish chorizo has a $R Q>1$.

\subsection{Meal suggestions for the consumption of meat and meat products}

On the light of the above results we calculated the recommended monthly maximum number of servings of each food $\left(R C_{m m}\right)$ as defined by the USEPA (USEPA, 2000) (Table 4). Thus, in adults the total consumption of meat could be maintained with a slight decrease (from 27.1 to 22.4 servings/month) but a significant reduction in the consumption of monthly rations of beef and pork meat (approximately one third), and chicken meat (approximately the half) should be recommended. The consumption of lamb meat should be limited to one serving every 4 or 5 months. In children, however, it would be advisable to reduce the total meat consumption (from 24.2 to 14.1 servings/month), and also to limit consumption of beef, pork and chicken so that children should consume at most five servings of these meats each month (considered together). Lamb consumption in children should be severely limited.

The current consumption of charcuterie products does not seem to be a problem in general and in almost all cases can be maintained and even increased if desired. The only exception within this group would be Spanish chorizo, for which consumption should be limited, especially in children.

\section{Discussion}

As expected, the pollutant values found in our sample of foods were similar to, but not fully comparable with, those described in the literature 
Table 3

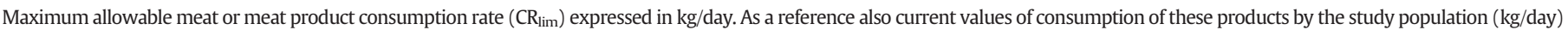
are included.

\begin{tabular}{|c|c|c|c|c|c|c|c|c|c|c|c|c|c|c|}
\hline & \multirow{2}{*}{$\begin{array}{l}\text { Current food } \\
\text { consumption } \\
\text { (kg/day) }\end{array}$} & \multicolumn{6}{|c|}{$\mathrm{CR}_{\lim }$ adults ( $\mathrm{kg} /$ day) } & \multirow{2}{*}{$\begin{array}{l}\text { Current food } \\
\text { consumption } \\
\text { (kg/day) }\end{array}$} & \multicolumn{6}{|c|}{$\mathrm{CR}_{\text {lim }}$ children ( $\mathrm{kg} /$ day) } \\
\hline & & $\sum \mathrm{DDT}$ & $\sum \mathrm{HCH}$ & HCB & $\sum \mathrm{M}-\mathrm{PCB}$ & $\sum \mathrm{DL}-\mathrm{PCB}$ & $\begin{array}{l}\sum_{\mathrm{P}_{\mathrm{eq}}} \mathrm{B}[\mathrm{a}] \\
\end{array}$ & & $\sum \mathrm{DDT}$ & $\sum \mathrm{HCH}$ & $\mathrm{HCB}$ & $\sum \mathrm{M}-\mathrm{PCB}$ & $\sum \mathrm{DL}-\mathrm{PCB}$ & $\sum_{\mathrm{P}_{\mathrm{eq}}} \mathrm{B}[\mathrm{a}]$ \\
\hline \multicolumn{15}{|l|}{ Meat } \\
\hline Beef & 0.0504 & 0.0953 & 0.0839 & 0.1034 & $0.0260^{*}$ & 0.5475 & 0.3327 & 0.0479 & 0.0490 & $0.0432^{*}$ & 0.1034 & $0.0134^{*}$ & 0.5475 & 0.1712 \\
\hline Chicken & 0.0427 & 0.2499 & 0.1650 & 0.1212 & 0.0484 & 2.6306 & 0.2451 & 0.0431 & 0.1286 & 0.0849 & 0.1212 & $0.0249^{*}$ & 2.6306 & 0.1262 \\
\hline Pork & 0.0241 & 0.0602 & 0.0369 & 0.0711 & $0.0158^{*}$ & 0.7436 & 0.0835 & 0.0195 & 0.0310 & $0.0190^{*}$ & 0.0711 & $0.0081^{*}$ & 0.7436 & 0.0430 \\
\hline Lamb & 0.0115 & $0.0063^{*}$ & $0.0040^{*}$ & $0.0014^{*}$ & 0.0120 & 0.3434 & 0.2008 & 0.0060 & $0.0033^{*}$ & $0.0021^{*}$ & $0.0014^{*}$ & 0.0062 & 0.3434 & 0.1033 \\
\hline Goat & 0.0004 & 0.2658 & 0.3180 & 0.1238 & 0.0599 & 1.3014 & 0.1386 & 0.00007 & 0.1368 & 0.1637 & 0.1238 & 0.0308 & 1.3014 & 0.0713 \\
\hline Rabbit & 0.0044 & 0.6642 & 0.6105 & 0.0752 & 0.1459 & 8.2424 & 0.9315 & 0.0025 & 0.3419 & 0.3142 & 0.0752 & 0.0751 & 8.2424 & 1.8440 \\
\hline \multicolumn{15}{|l|}{$\begin{array}{l}\text { Meat } \\
\quad \text { products }\end{array}$} \\
\hline $\begin{array}{l}\text { Iberian } \\
\text { cured ham }\end{array}$ & 0.0112 & 0.2296 & 0.4770 & 0.0631 & 0.0343 & 0.7359 & 0.5680 & 0.0076 & 0.1182 & 0.2455 & 0.0631 & 0.0177 & 0.7359 & 0.2923 \\
\hline Ham & 0.0117 & 0.7949 & 1.3874 & 3.0292 & 0.1594 & 7.2727 & 0.9315 & 0.0129 & 0.4091 & 0.7141 & 3.0292 & 0.0821 & 7.2727 & 3.1963 \\
\hline $\begin{array}{l}\text { Spanish } \\
\text { chorizo }\end{array}$ & 0.0089 & 0.1550 & 0.2212 & 0.1723 & 0.0280 & 0.8270 & 0.0104 & 0.0115 & 0.0798 & 0.1138 & 0.1723 & 0.0144 & 0.8270 & $0.0054^{*}$ \\
\hline $\begin{array}{l}\text { Spanish } \\
\text { salchichón }\end{array}$ & 0.0029 & 0.0797 & 0.3013 & 0.0484 & 0.0199 & 1.3014 & 1.8630 & 0.0034 & 0.0410 & 0.1551 & 0.0484 & 0.0102 & 1.3014 & 0.9589 \\
\hline Bacon & 0.0016 & 0.0804 & 0.1974 & 0.0159 & 0.0095 & 2.1317 & 0.4273 & 0.0011 & 0.0414 & 0.1016 & 0.0159 & 0.0049 & 2.1317 & 0.2199 \\
\hline $\begin{array}{l}\text { Italian } \\
\text { mortadella }\end{array}$ & 0.0013 & 0.1569 & 0.4625 & 0.0770 & 0.0295 & 0.9366 & 0.9315 & 0.0044 & 0.0807 & 0.2381 & 0.0770 & 0.0152 & 0.9366 & 1.0654 \\
\hline
\end{tabular}

* The $\mathrm{CR}_{\text {lim }}$ for these carcinogens is exceeded with the current pattern of food consumption.

in other regions of the world, which is logical because it is common to find regional variations (sometimes very significant) in the reported pollutant concentrations (Costabeber et al., 2006; Letta and Attah, 2013; Malisch and Kotz, 2014; Pardio et al., 2012; Polder et al., 2010; Schecter et al., 2010; Tornkvist et al., 2011; Wang et al., 2011). It is also important to note that for some of the foods included in this study, we found no reference data in the literature. Therefore, to make a realistic estimate, in this study we preferred to directly quantify the contaminants in a representative sample of the main types of meat and charcuterie products in the consumers' market basket, as the main goal of this study was not to perform a monitoring study and establish comparisons with other available studies but to provide an estimate of carcinogenic risk associated to relevant carcinogens through meat consumption in the Spanish population.

Although our results showed that $100 \%$ of the food samples investigated had quantifiable amounts of the majority of the carcinogens included in the study, and that we found very similar concentrations in the extracted fats among type of meats and charcuterie products, the quantification referred to fresh products was fairly different among food items. Thus, in relation to the types of meats, we observed that, by far, lamb meat was the most contaminated by all types of pollutants ( $\sum$ OCPs, $\sum$ PCBs, and $\sum$ c-PAHs), followed by pork and beef, and that the less contaminated meats were rabbit and goat meats. This is mainly in relation to the percentage of fat presented by each type of meat. The case of the traditional charcuterie products is most striking, as the differences in contaminant levels in fat were in general minimal; however, in the fresh product, the differences became very relevant. Thus, the charcuterie product most contaminated by $\sum$ PCBs and $\sum$ OCPs was bacon, and the more contaminated by $\sum$ c-PAHS was by far Spanish chorizo. The least contaminated of the charcuterie products (by all contaminants) was ham in its two varieties.

Dietary exposure calculations are performed by combining data on consumption habits with the concentrations of contaminants found in food samples. The estimation of food contaminant exposure is a topic of growing interest in the field of public health as a means to inform and guide the actions on Food Security and Nutrition as a predictive method for determining the state of health of populations. For this reason, the European Food Safety Authority (EFSA) performs a collection of food consumption data from the different Member States, which must develop nutritional surveys in their territories. For this study we have used the data provided by the AECOSAN (AECOSAN, 2011). From our estimates, the meat-driven EDIs of some of the carcinogens considered were well below the tolerable daily intakes (TDIs) established by the
World Health Organization for these contaminants (JECFA, 2000). Thus, the intake of $\sum$ DDTs and $\sum$ HCHs represented less that $1.2 \%$ of those TDIs. However for other pollutants the exposure is considerably higher. Thus, for HCB the EDI reaches $16 \%$ of its TDI (mainly related to lamb consumption). This was also the case for the exposure to $\sum$ TEQ $_{D L-P C B s}$ since the estimated EDI would represent $9 \%$ or $19 \%$ (in adults and children, respectively) of the TDI of $2 \mathrm{pg} / \mathrm{kg}$ b.w. day (SCF, 2000). Moreover if we used the upper bound approach for calculations (as recommended by the European Commission (SCF, 2000)) our estimates would be almost triple, and therefore, the exposure through the consumption of meat and charcuterie products would represent as much as $44 \%$ of the TDI in children. These results are worrisome because the possibility exists that certain consumers may be subject to high dietary exposures to dioxins, having into consideration that it has been established that intake of DL-PCBs would represent almost 70\% of total dioxin dietary exposure (SCF, 2000; Tornkvist et al., 2011). Finally, with respect to exposure to $\sum$ c-PAHs, the WHO has not yet established TDI values for c-PAHs. However other references may be used and thus, using the Contaminated Land Exposure Assessment model of UK, which has established a TDI for B[a] $\mathrm{P}_{\mathrm{eq}}$ of $20 \mathrm{ng} / \mathrm{kg}$ b.w. day (CLEA-UK, 2008), the current meat consumption in the evaluated population would represent between 113 and $284 \%$ of these values, particularly due to the consumption of Spanish chorizo (a smoke cured type of sausage) and lamb. It is logical that Spanish chorizo is one of the major contributors to PAHs exposure because the manufacturing of Spanish chorizo implies the smoking of the pieces during the first 5 days of ripening using smoke from wood (Lorenzo et al., 2011), and among the more than 400 volatile components recorded in biomass smoke composition, the PAHs are present at high concentrations (Lorenzo et al., 2011). One should also keep in mind that dietary exposure to these contaminants could be even higher than those reported in this study, since it is well known that the way in which food is cooked, processed, and packaged may introduce chemicals (such as bisphenol A, phthalates, acrylamide) that are not present in the raw food, or increase their content in those naturally occurring pollutants (such as PAHs) (Pieters and Focant, 2014; Vogt et al., 2012).

It has been established that the RQ evaluation is a good method to estimate the risk of a population and to establish exposure limits to chemicals (USEPA, 2000). It is well known that chemical contaminants in foods, which are usually present in mixtures of various compounds belonging to different chemical classes, may exert their adverse effects on consumers interacting with each other in synergistic, additive or 


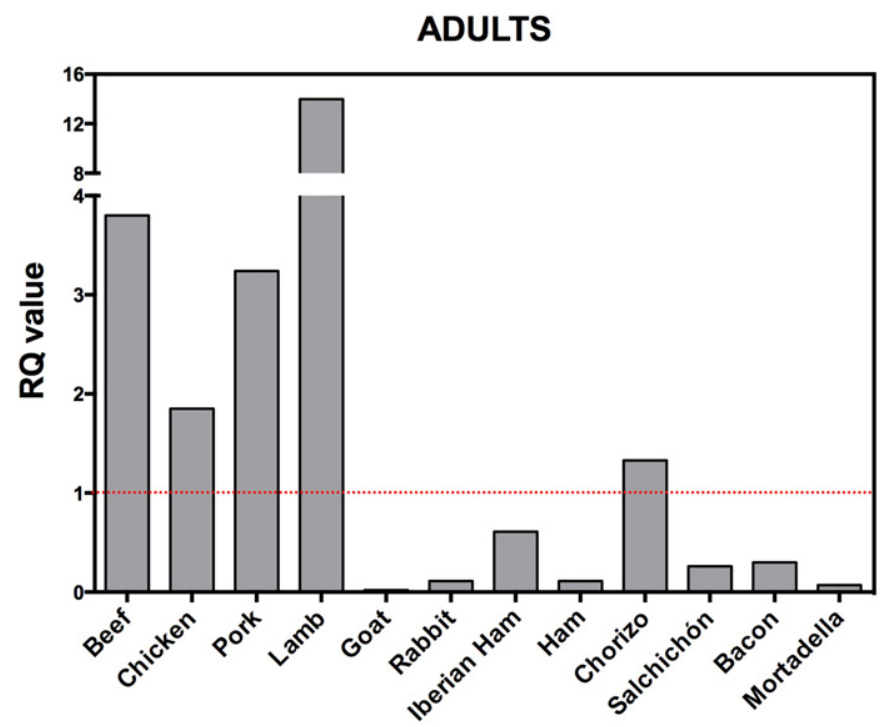

\section{CHILDREN}

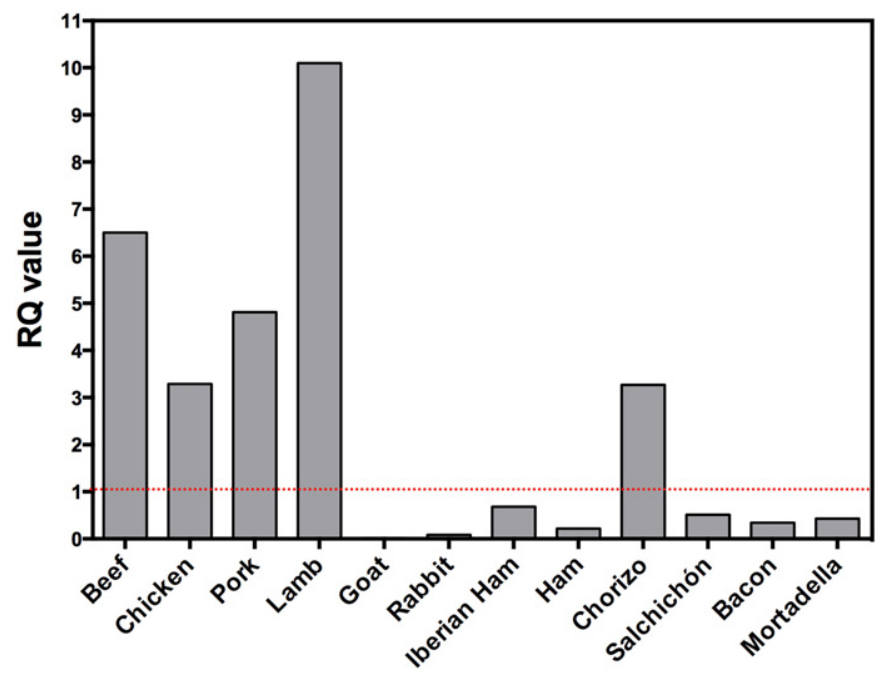

Fig. 2. Hazard ratios of the contaminants for carcinogenic effects in adults (upper panel) and children (lower panel) via consumption of meat and charcuterie products. The red line indicates the threshold for carcinogenic risk $(R Q=1)$.

even in antagonistic manners. However, the calculation model of the RQ implies the assumption that all pollutants cause similar toxicological effects and that the combined effect is the sum of the individual effects (USEPA, 2000). As recommended by the USEPA for calculating the RQ of some other food items (such as fish) (USEPA, 2000), we have considered that all carcinogens studied are similar and therefore we have used the additive model. To calculate RQ first it is necessary to calculate the $\mathrm{CR}_{\text {lim }}$, which is based on the load of each pollutant for each one of the food items. According to our results the maximum allowable consumption rates are currently being exceeded in Spanish population for various carcinogens. According the USEPA (USEPA, 2000) it can be assumed that a $\mathrm{RQ} \leqq 1$ means that there is not an appreciable risk of carcinogenicity associated to the consumption of a particular food. Thus, in this study we found that the current consumption rate of several meat and charcuterie products by the Spanish population (considering all carcinogens together), has a RQ $>1$ for pork, chicken, Spanish chorizo, and especially high for lamb ( $R Q>10)$, and for beef in children ( $R Q>6)$, and therefore the consumption of these foods is associated to carcinogenic risk.
Table 4

Recommended maximum number of meals per month of each food item.

\begin{tabular}{|c|c|c|c|c|}
\hline & \multicolumn{2}{|l|}{ Adults } & \multicolumn{2}{|l|}{ Children } \\
\hline & $\begin{array}{l}\text { Current } \\
\text { pattern of } \\
\text { consumption }^{\mathrm{a}} \\
\text { (meals/month) } \\
C_{m m}\end{array}$ & $\begin{array}{l}\text { Maximum } \\
\text { recommended } \\
\text { consumption } \\
\text { (meals/month) } \\
R C_{m m}\end{array}$ & $\begin{array}{l}\text { Current } \\
\text { pattern of } \\
\text { consumption a }^{\text {a }} \\
\text { (meals/month) } \\
C_{m m}\end{array}$ & $\begin{array}{l}\text { Maximum } \\
\text { recommended } \\
\text { consumption } \\
\text { (meals/month) } \\
R C_{m m}\end{array}$ \\
\hline Beef & 10.2 & 2.7 & 9.7 & 1.5 \\
\hline Pork & 4.9 & 1.5 & 4.0 & 0,8 \\
\hline Chicken & 8.7 & 4.7 & 8.7 & 2.7 \\
\hline Lamb & 2.3 & 0.2 & 1.2 & 0.1 \\
\hline Goat & 0.1 & 5.1 & 0.0 & 3.0 \\
\hline Rabbit & 0.9 & 8.3 & 0.5 & 6.1 \\
\hline Total meat & 27.1 & 22.4 & 24.2 & 14.1 \\
\hline Iberian ham & 4.9 & 8.0 & 3.3 & 4.8 \\
\hline Ham & 5.1 & 44.4 & 5.6 & 25.9 \\
\hline Spanish chorizo & 3.9 & 2.9 & 5.0 & 1.5 \\
\hline $\begin{array}{l}\text { Spanish } \\
\text { salchichón }\end{array}$ & 1.3 & 4.9 & 1.5 & 2.9 \\
\hline Bacon & 0.7 & 2.3 & 0.5 & 1.4 \\
\hline $\begin{array}{l}\text { Italian } \\
\text { mortadella }\end{array}$ & 0.6 & 7.6 & 1.9 & 4.5 \\
\hline $\begin{array}{l}\text { Total } \\
\text { charcuterie } \\
\text { products }\end{array}$ & 16.4 & 70.1 & 17.8 & 41.0 \\
\hline
\end{tabular}

a Data obtained from AECOSAN, 2011.

Based on the levels of contaminants found in the foods of this study, on the calculations done, and also assuming that consumers want to maintain their monthly intake of protein from meat and charcuterie products (i.e., the number of servings per month would not change substantially), we calculated the maximum number of meals of each food item that would not pose a carcinogenic risk to make consumption recommendations (this is, consumption which that would allow a RQ $\leqq 1$ for all products). In general, if the adult consumer wants to maintain a high intake of meat, it would be advisable to increment the consumption of rabbit and goat meat, and considerably reduce (50-80\%) the consumption of the rest. The recommendation for children would be a reduction in both, the total intake of servings per month of meat to almost $50 \%$, and also not to surpass the number of 5 servings of beef/ pork/chicken (considered together). With respect to charcuterie products, the current consumption could be maintained or even incremented for both, adults and children, except for Spanish chorizo, whose consumption should be reduced in adults and especially in children.

We conclude that the consumption of beef, pork, chicken, Spanish chorizo, and lamb all have a high carcinogenic risk for consumers. To diminish the continued exposure at very low doses of carcinogens, the monthly consumption of these products should be considerably reduced.

\section{Conflict of interest}

The authors declare no conflict of interest.

\section{Acknowledgments}

The authors would like to thank Mrs. María de los Reyes Suarez Hanna for her technical assistance.

\section{References}

Abid, Z., Cross, A.J., Sinha, R., 2014. Meat, dairy, and cancer. Am. J. Clin. Nutr. 100, 386S-393S.

AECOSAN, 2011. ENIDE: National Survey of Dietary Intake (2009-2010). Results on Consumption Data. Agencia Española de Seguridad Alimentaria y Nutrición, Gobierno de España.

Alexander, D.D., Cushing, C.A., 2009. Quantitative assessment of red meat or processed meat consumption and kidney cancer. Cancer Detect. Prev. 32, 340-351. 
Alexander, D.D., Mink, P.J., Cushing, C.A., Sceurman, B., 2010. A review and meta-analysis of prospective studies of red and processed meat intake and prostate cancer. Nutr. J 9,50 .

Aune, D., Chan, D.S., Vieira, A.R., Navarro Rosenblatt, D.A., Vieira, R., Greenwood, D.C., et al 2013. Red and processed meat intake and risk of colorectal adenomas: a systematic review and meta-analysis of epidemiological studies. Cancer Causes Control 24 611-627.

Boada, L.D., Lara, P.C., Alvarez-Leon, E.E., Losada, A., Zumbado, M.L., Liminana-Canal, J.M. et al., 2007. Serum levels of insulin-like growth factor-I in relation to organochlorine pesticides exposure. Growth Hormon. IGF Res. 17, 506-511.

Boada, L.D., Zumbado, M., Henriquez-Hernandez, L.A., Almeida-Gonzalez, M., AlvarezLeon, E.E., Serra-Majem, L., et al., 2012. Complex organochlorine pesticide mixtures as determinant factor for breast cancer risk: a population-based case-control study in the Canary Islands (Spain). Environ. Health 11, 28.

Boada, L.D., Sangil, M., Alvarez-Leon, E.E., Hernandez-Rodriguez, G., Henriquez-Hernandez L.A., Camacho, M., et al., 2014. Consumption of foods of animal origin as determinant of contamination by organochlorine pesticides and polychlorobiphenyls: results from a population-based study in Spain. Chemosphere 114, 121-128

Camacho, M., Luzardo, O.P., Boada, L.D., Lopez Jurado, L.F., Medina, M., Zumbado, M., et al 2013. Potential adverse health effects of persistent organic pollutants on sea turtles: evidences from a cross-sectional study on Cape Verde loggerhead sea turtles. Sci. Total Environ. 458-460C, 283-289.

Camacho, M., Boada, L.D., Oros, J., Lopez, P., Zumbado, M., Almeida-Gonzalez, M., et al., 2014. Monitoring organic and inorganic pollutants in juvenile live sea turtles: results from a study of Chelonia mydas and Eretmochelys imbricata in Cape Verde. Sci. Total Environ. 481C, 303-310.

Casals-Casas, C., Desvergne, B., 2011. Endocrine disruptors: from endocrine to metabolic disruption. Annu. Rev. Physiol. 73, 135-162.

Chamorro, A., Miranda, F.J., Rubio, S., Valero, V., 2012. Innovations and trends in meat consumption: an application of the Delphi method in Spain. Meat Sci. 92, 816-822.

CLEA-UK, 2008. Contaminated Land Exposure Assessment Model (CLEA-UK). PB CLEA UK v. 4. Handbook. 2014

Costabeber, I., Dos Santos, J.S., Xavier, A.A., Weber, J., Leaes, F.L., Junior, S.B., et al., 2006. Levels of polychlorinated biphenyls (PCBs) in meat and meat products from the state of Rio Grande do Sul, Brazil. Food Chem. Toxicol. 44, 1-7.

de Langen, H., 1963. Determination of fat in meat and separable fat by the Gerber test. N. Engl. J. Agric. Res. 6, 452-456.

Dorgan, J.F., Brock, J.W., Rothman, N., Needham, L.L., Miller, R., Stephenson Jr., H.E., et al., 1999. Serum organochlorine pesticides and PCBs and breast cancer risk: results from a prospective analysis (USA). Cancer Causes Control 10, 1-11.

EFSA, 2008. Polycyclic aromatic hydrocarbons in food. Scientific opinion of the panel on contaminants in the food chain. EFSA J. 724, 1-114.

EN, 1996a. European Norm 1528-2. Fatty Food - Determination of Pesticides and Polychlorinated Biphenyls (PCBs) - Part 2: Extraction of fat, Pesticides and PCBs, and Determination of fat Content. European Committee for Standardization.

EN, 1996b. European norm 1528-3. Fatty food. Determination of pesticides and polychlorinated biphenyls (PCBs). Clean-up Methods. European Committee for Standardization.

EPA, 2001. United States Environmental Protection Agency, Office of Environmental Information, Emergency Planning and Community Right-to-Know Act - Section 313: Guidance for Reporting Toxic Chemicals: Polycyclic Aromatic Compounds Category. EPA (260-B-01-03)

EPA, 2014. Integrated risk information system (IRIS). Full List of IRIS Chemicals.

Ferlay, J., Steliarova-Foucher, E., Lortet-Tieulent, J., Rosso, S., Coebergh, J.W., Comber, H., et al., 2013. Cancer incidence and mortality patterns in Europe: estimates for 40 countries in 2012. Eur. J. Cancer 49, 1374-1403.

Freedman, N.D., Cross, A.J., McGlynn, K.A., Abnet, C.C., Park, Y., Hollenbeck, A.R., et al., 2010. Association of meat and fat intake with liver disease and hepatocellular carcinoma in the NIH-AARP cohort. J. Natl. Cancer Inst. 102, 1354-1365.

Gasull, M., Bosch de Basea, M., Puigdomenech, E., Pumarega, J., Porta, M., 2011. Empirica analyses of the influence of diet on human concentrations of persistent organic pollutants: a systematic review of all studies conducted in Spain. Environ. Int. 37 $1226-1235$.

Giacosa, A., Barale, R., Bavaresco, L., Gatenby, P., Gerbi, V., Janssens, J., et al., 2013. Cance prevention in Europe: the Mediterranean diet as a protective choice. Eur. J. Cancer Prev. 22, 90-95

Gilsing, A.M., Berndt, S.I., Ruder, E.H., Graubard, B.I., Ferrucci, L.M., Burdett, L., et al., 2012 Meat-related mutagen exposure, xenobiotic metabolizing gene polymorphisms and the risk of advanced colorectal adenoma and cancer. Carcinogenesis 33, 1332-1339.

JECFA, 2000. Joint FAO/WHO meetings on pesticide residues 2000. Expert Committee on Food Additives, FAO Plant Production and Protection Paper 163/59 5. JEFCA, p. 28.

Kanerva, M., 2013. Meat Consumption in Europe: Issues, Trends and Debates. Sustainability Research Center (ARTEC) - University of Bremen, pp. 1-60.

Kim, E., Coelho, D., Blachier, F., 2013. Review of the association between meat consumption and risk of colorectal cancer. Nutr. Res. 33, 983-994.

Knerr, S., Schrenk, D., 2006. Carcinogenicity of "non-dioxinlike" polychlorinated biphenyls. Crit. Rev. Toxicol. 36, 663-694.
Larsson, S.C., Orsini, N., 2014. Red meat and processed meat consumption and all-cause mortality: a meta-analysis. Am. J. Epidemiol. 179, 282-289.

Leon-Munoz, L.M., Guallar-Castillon, P., Graciani, A., Lopez-Garcia, E., Mesas, A.E., Aguilera, M.T., et al., 2012. Adherence to the Mediterranean diet pattern has declined in Spanish adults. J. Nutr. 142, 1843-1850.

Letta, B.D., Attah, L.E., 2013. Residue levels of organochlorine pesticides in cattle meat and organs slaughtered in selected towns in West Shoa Zone, Ethiopia. J. Environ. Sci. Health B 48, 23-32.

Liao, L.M., Hofmann, J.N., Kamangar, F., Strickland, P.T., Ji, B.T., Yang, G., et al., 2014. Polycyclic aromatic hydrocarbons and risk of gastric cancer in the Shanghai Women's Health Study. Int. J. Mol. Epidemiol. Genet. 5, 140-144.

Lorenzo, J.M., Purrinos, L., Bermudez, R., Cobas, N., Figueiredo, M., Garcia Fontan, M.C. 2011. Polycyclic aromatic hydrocarbons (PAHs) in two Spanish traditional smoked sausage varieties: “Chorizo gallego" and "Chorizo de cebolla". Meat Sci. 89, 105-109.

Luzardo, O.P. Ruiz-Suarez, N., Henriquez-Hernandez, L. A., Valeron, P.F., Camacho, M. Zumbado, M., et al., 2014. Assessment of the exposure to organochlorine pesticides, PCBs and PAHs in six species of predatory birds of the Canary Islands, Spain. Sci. Total Environ. 472, 146-153.

Malisch, R., Kotz, A., 2014. Dioxins and PCBs in feed and food - review from European perspective. Sci. Total Environ. 491-492, 2-10.

Nisbet, I.C.T., LaGoy, P.K., 1992. Toxic equivalent factors (TEFs) for polycyclic aromatic hydrocarbons (PAHs). Regul. Toxicol. Pharmacol. 16, 290-300.

Pardio, V., Martinez, D., Flores, A., Romero, D., Suarez, V., Lopez, K., et al., 2012. Human health risk of dietary intake of organochlorine pesticide residues in bovine meat and tissues from Veracruz, Mexico. Food Chem. 135, 1873-1893.

Pericleous, M., Rossi, R.E., Mandair, D., Whyand, T., Caplin, M.E., 2014. Nutrition and pancreatic cancer. Anticancer Res. 34, 9-21.

Pieters, R., Focant, J.F., 2014. Dioxin, furan and PCB serum levels in a South African Tswana population: comparing the polluting effects of using different cooking and heating fuels. Environ. Int. 66, 71-78

Polder, A., Savinova, T.N., Tkachev, A., Loken, K.B., Odland, J.O., Skaare, J.U., 2010. Levels and patterns of Persistent Organic Pollutants (POPS) in selected food items from Northwest Russia (1998-2002) and implications for dietary exposure. Sci. Total Environ. 408, 5352-5361.

SCF, 2000. Opinion of the Scientific Committee on Food (SCF) on the risk assessment of dioxins and dioxin-like PCBs in food. Update Based on new Scientific Information Available Since the Adoption of the SCF Opinion of 22nd November 2000.

Schecter, A., Colacino, J., Haffner, D., Patel, K., Opel, M., Papke, O., et al., 2010. Perfluorinated compounds, polychlorinated biphenyls, and organochlorine pesticide contamination in composite food samples from Dallas, Texas, USA. Environ. Health Perspect. 118, 796-802.

Schwarz, M.A., Lindtner, O., Blume, K., Heinemeyer, G., Schneider, K., 2014. Dioxin and dlPCB exposure from food: the German LExUKon project. Food Addit. Contam. Part A Chem. Anal. Control Expo. Risk Assess. 31, 688-702.

Tornkvist, A., Glynn, A., Aune, M., Darnerud, P.O., Ankarberg, E.H., 2011. PCDD/F, PCB, PBDE, HBCD and chlorinated pesticides in a Swedish market basket from 2005-levels and dietary intake estimations. Chemosphere 83,193-199.

Trafialek, J., Kolanowski, W., 2014. Dietary exposure to meat-related carcinogenic substances: is there a way to estimate the risk? Int. J. Food Sci. Nutr. 65, 774-780.

USEPA, 2000. Guidance for assessing chemical contaminant data for use in fish advisories. Risk Assessment and Fish Consumption Limits, Third ed. vol. 2 (http://water.epa.gov/ scitech/swguidance/fishshellfish/techguidance/risk/volume2_index.cfm).

Valeron, P.F., Pestano, J.J., Luzardo, O.P., Zumbado, M.L., Almeida, M., Boada, L.D., 2009. Differential effects exerted on human mammary epithelial cells by environmentally relevant organochlorine pesticides either individually or in combination. Chem. Biol. Interact. 180, 485-491.

Van den Berg, M., Birnbaum, L.S., Denison, M., De Vito, M., Farland, W., Feeley, M., et al., 2006. The 2005 World Health Organization reevaluation of human and mammalian toxic equivalency factors for dioxins and dioxin-like compounds. Toxicol. Sci. 93, 223-241.

Varela-Moreiras, G., Ruiz, E., Valero, T., Avila, J.M., del Pozo, S., 2013. The Spanish diet: an update. Nutr. Hosp. 28 (Suppl. 5), 13-20.

Vogt, R., Bennett, D., Cassady, D., Frost, J., Ritz, B., Hertz-Picciotto, I., 2012. Cancer and noncancer health effects from food contaminant exposures for children and adults in California: a risk assessment. Environ. Health 11, 83.

Wang, H.S., Sthiannopkao, S., Du, J., Chen, Z.J., Kim, K.W., Mohamed Yasin, M.S., et al., 2011. Daily intake and human risk assessment of organochlorine pesticides (OCPs) based on Cambodian market basket data. J. Hazard. Mater. 192, 1441-1449.

WHO, 2014. IARC monographs on the evaluation of carcinogenic risks to humans. Agents Classified by the IARC Monographs. IARC

Yu, Y., Wang, X., Yang, D., Lei, B., Zhang, X., Zhang, X., 2014. Evaluation of human health risks posed by carcinogenic and non-carcinogenic multiple contaminants associated with consumption of fish from Taihu Lake, China. Food Chem. Toxicol. 69, 86-93.

Zhu, H.C., Yang, X., Xu, L.P., Zhao, L.J., Tao, G.Z., Zhang, C., et al., 2014. Meat consumption is associated with esophageal cancer risk in a meat- and cancer-histological-type dependent manner. Dig. Dis. Sci. 59, 664-673. 